\title{
Firm's operant resources and service value - A customer perspective in health care service
}

- Pham Ngoc Thuy

- Nguyen Tran Cam Linh

- Nguyen Tien Dung

- Pham Tien Minh

University of Technology, VNU HCM - Email: pnthuy@hcmut.edu.vn

(Manuscript Received on May 20 ${ }^{\text {th }}$, 2015; Manuscript Revised on August ${ }^{\text {rd }}$, 2015)

\begin{abstract}
This study aims to examine how a that firm's operant resources as viewed by customer's perception of a firm's operant resources (representational, cultural and social resources) affects the service value in a highly interaction service context. An empirical analysis was conducted on 263 patients in customers have a significant impact on perceived service value. Of which, the cultural resource has the strongest weight on customer perceived value. Discussions and managerial implications have been presented accordingly.
\end{abstract}

health care service in Vietnam. The results show

Keyword: firm's operant resources, service value, word-of-mouth, health care services.

\section{INTRODUCTION}

The term of value is essential for any firms [52] but it is not consistently understood by researchers because of its overuse in variety of fields such as finance, economics, management, information systems, ethics, marketing... [36]. Albeit different views, most scholars in service marketing agree that service value is formed by the perception of customers when experiencing any kinds of service [36; 33]. Customers' service experience might be associated with both benefits that they enjoy after using a service and what they have during the service process [33].

In service dominant logic view (SDL), firms and customers are considered as value co- creators [48] and both have to integrate their resources including operand and operant ones, to create value for customers. Based on the resource-advantage theory [40], firms are required to focus on the intangible, dynamic, operant resources to enhance firm's competitive advantage and performance. Firm's operant resources which refer to reputation, employees' skills/knowledge, relationship ... [6] play an important role in the value creating process [48; 49]. Moreover, operant resources with their characteristics of dynamic and infinite can create additional operant resources [48]. Therefore, it is obviously for service firms to understand the way their operant resources are employed to co-create value with customers. 
More than that, to the service where the quality of outcomes heavily depends on the service encounter credence and requires a certain level of customer participation at each encounter in the service process, there are two questions to be concerned: How customers evaluate operant resources of a service firm during an intensity interaction process? And what kind of firm's operant resources has the strongest effect on customer's service value which leads to positive word-of-mouth?

Based on the aforementioned analysis, this study is to investigate the different impacts of a firm's operant resources including representational, cultural and social relational resources on service value as perceived by customers, and to revalidate the relationship of perceived value and positive word-of-mouth effect. The health care service was chosen because this service requires the participation of patient during service process. The study was conducted in HoChiMinh city where this service occupies the biggest market share in Vietnam, which served 31 million cases in 2013 (according to HCMC General Statistics Office).

Following this introduction, the literature review and hypothesis development, method, result, discussion and conclusion are presented.

\section{LITERATURE REVIEW AND RESEARCH METHOD}

\subsection{Service value}

Service value is defined as a consumer's overall assessment of the utility of a service based on perceptions of what is received and what is given [53]. There have been several approaches to the dimensionality of this highly abstract construct [4]. For a parsimonious reason, the current study adopts service value as consisting of two interrelated components, namely process value (or functional value) and outcome value (or technical value) $[31 ; 32]$.
Process value is the value which customers experience during the service process while outcome value refers to customer's perception of its outcome benefits after using the service [31].

The service-dominant logic (S-D logic) [48; 49] emphasizes the role of customers as value co-creators. In the service process, value for customers is created and varied across different customers who possess different skills and knowledge [48; 25]. In contrast, providers play the role of value facilitators who provide foundations to facilitate customer's value creation [25]. If service firms want to actively join in the process, they have to understand their customers. To do that, firms need to interact with their customers through which their operant resources can be deployed and integrated into the customer's value creation process [25].

\subsection{Firm's operant resources and service} value

\section{Firm's operant resources}

To any services, interaction is a requirement for collaboration and the creation of value [27]. Emphasizing the two sides of value creation process of customer and service provider, Grönroos [24] explains that the provider offers its resources, competencies and processes to the customers. These resources can differ in terms of quality and quantity and require complementarities, or can be mixed forms [27].

In general, a firm's resources can be categorized as operand resources and operant resources. Operand resources are the typical material properties such as financial resources, infrastructure, and legal ownership while operant resources are the typical factors related to human, organization, communication and relationships [14]. They have different features in terms of value and the ability to copy [13]. Operant resources of a firm represent its

\section{Trang 144}


capacity and capabilities that fluctuate when firms adapt to the surroundings to maintain operations and create value [6]. Although operant resources are properties of a firm, they can be observed and evaluated by customers through interaction process [13]. On this view, Baron and Warnaby [6] describe operant resources of a firm under the clients' perspective through three elements: representational resources (reputation, credibility and comfort), cultural resources (knowledge, management skills, capacity, quality of service and technical expertise), and social resources (the friendliness of staff, relations, $\mathrm{C} 2 \mathrm{C}$ networking).

According to Vargo and Lusch [48], during the service interaction process, customers may assess the firm operant resources which are manifested via frontline staff's capability and skills (i.e., cultural resources). Moreover, when customers take part in the service process, they experience service scripts at each of service encounters. Service value at that time will be formed via their behavioral procedures. The form of "activity-based experience" or "mental experience" provides customers with chances to see how good the firm provides operant resources to assist them having better service value [33].

\section{Representational resources and service value relationship}

Representational resources are related to firm image or reputation that customers feel about a service provider when making decisions to choose its service. Representational resources mostly imply a customer's positive mood, reflecting hospitality and reasonable comfort that he or she feels about the firm [6]. They are results of a competitive process in which the firm expressed the features to get a good position in society [46].
In health care service, a hospital's representational resources are formed by patients' trust about its treatment ability, reliability and reputation. Before choosing a hospital, the information that patients are always aware of is about its reputation and reliability from previous patients or own experience. They use their own knowledge and skills during experiencing the treatment [25] to justify how good and reliable this service is.

Firm's representational resources including brand image and brand reputation are mainly associated with good service performance or service quality [50] that the customers have experienced in the past, or learned from other customers, or from the public at large. The literature on service also establishes that service quality is a key to service value [53]. Thus it is reasonable to believe that hospital's reputation, brand, and image have positive impacts on perceived service value. In other words, hospital's representational operation resources have positive impacts on patients' perceived service value.

H1: A hospital's representational resources have positive impacts on perceived service value of patients using its service.

\section{Cultural Resources and service value relationship}

Baron and Warnaby [6] suggest that the firm's cultural resources which can be observed by customers include those reflective manifestations like cultural ethos, knowhow/technology, capabilities and service quality [6]. Within this empirical research, which was conducted in health care service, patients can reliably observe the firm's service quality rather than other mentioned aspects. Therefore, we focus only on perceived service quality as the main representative of firm's cultural resources in the view of customers. Moreover, service 
quality is basically a multi-dimensional construct, of which Dagger, Sweeney and Johnson [16] have developed several subdimensions specifically in the health care service. Accordingly, the three sub-dimensions of service quality which are most relevant to patients in Vietnam are staff expertise (i.e., technical quality), service procedure (i.e., administrative quality) and staff interaction (i.e., interpersonal quality). Staff expertise describes what the customer receives as a result of the interactions with the staff of a service company $[9 ; 18 ; 22 ; 44]$. Staff expertise reflects the ability of a service provider adhering to high standards of service delivery [54]. Adapting this notion to this specific research setting, staff expertise is manifested by the capacity and knowledge of physicians. Service procedure does not only facilitate the production of the core values of a service but also increases the value in use for customers [23; 38]. This service procedure is reflected by timeliness, organizational management (i.e., the collaboration between the departments, the ability to organize and manage services, and support (i.e., convenience and ease in the administrative procedures for customers) [16; 51]. Staff interaction refers the communication between service employee and customer [9; 22]. It covers three core themes: manner, communication and relationship. Manner relates to the customer's perception of the attitude of service provider or service provider's employees in common discussion. Communication refers to the interaction between service provider and customer which bears a nature of interpersonal process and information transfer between both parties. Relationship refers to the close and strong relationship between a provider and a customer [16].

When experiencing a health care service, patients embed their bodies and mentality during the treatment process. Consequently, they are aware how the hospital's employees show comfort and goodwill, especially how skillful physicians are, they have good interaction with patients; and the service process is reasonable and effective or not. The interaction of patients at each service encounter creates chances for patients to give more their own resources, gain more control and acquire more specific service to reach their expected value. The quality of interaction may be additional value if patients feel that the service process and outcome are controlled $[10 ; 3 ; 45 ; 15]$ along with value from the core service; and/or creating extra value by close relationships between patients and physicians $[10 ; 21]$. In other words, the feeling of good interaction of patients during the treatment process leads them to the perception of higher value. Therefore, it is hypothesized that:

H2: A hospital's cultural resources have positive impacts on perceived service value of patients using its service.

Social resources and service value relationship

Social resources are those relating to the relationships between a firm and its customers; between a firm and its employees, and between a firm and its partners and community [6]. Social resources can be viewed as organizational or individual network [19] referring to face-toface relationships and informal interpersonal exchange [17].

Madhavaram, Granot and Badrinarayanan [39] propose that a firm's social resources are represented by network competence, which help to establish relationships with other firms or individuals. Firms with strong social resources often achieve superior performance [8] that leads to customer satisfaction and perceived value [12; 43]. Bolton, Smith and Wagner [7]

\section{Trang 146}


find that social resources have a strong effect on customer perceived value.

Apply to the health care service, social resources of a hospital can be seen as its relationships to other health care centers by exchanging professional physicians, using medical facilities... To show good connection with other parties, the hospital proves that it has a strong capability, competence to use a wide variety of the diagnostic or treatment plans for patients through the exchange and/or cooperation with other health care centers. Therefore, when recognizing the hospital's strong social relationships, patients feel more trust on the service offerings which results to the high value perceived by them. The high assessment leads to the high perception of service value. Therefore, it is hypothesized that:

H3: A hospital's social resources have positive impacts on perceived service value of patients using its service.

\subsection{Service value and positive word-of-} mouth effect
Word-of-mouth effect refers to a process of personal influence, in which interpersonal communications between customers can change the customer's behavior or attitudes $[47 ; 29]$. This effect is believed to result from a positive evaluation of an acquired service [1]. Hartline and Jones [30] find a significant influence of perceived value on word-of-mouth, especially in the service context. In the context of health care service, patients are unwilling to use the service again. Therefore, loyalty through repeat patronization is not appropriate, whereas loyalty through positive word-of-mouth can be a powerful marketing tool. Ferguson et al. [20] find that perceived value significantly affect word-of-mouth related to recommending the hospital to potential patients. Therefore, it is hypothesized that:

H4. There is a positive impact of patients, perceived service value on their word-of-mouth effect.

The firm's operant resources and service value model is developed as follows:

\section{Figure 1. The proposed research model}

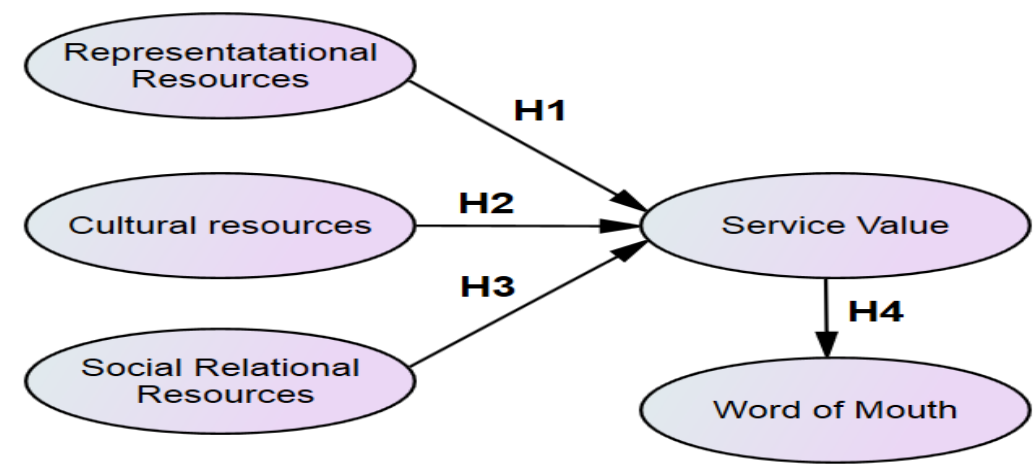

\section{METHOD}

The target respondents of this empirical research were the patients in HoChiMinh city. Data were collected by face-to-face interview and online survey using structured questionnaire which was administered at several hospitals and clinics. Convenient sampling was used in this study.

The measurement scales for representational resources (3 items) and social resources (3 items) were new developed based on Baron \& Warnaby [6] definitions. The measurement 
scales of cultural resources including service procedure (4 items), staff expertise (4 items) and staff interaction (8 items) were adjusted from Dagger et al. [16]. The scale measuring wordof-mouth was derived from Chaudhuri [11] and Jurisic and Azevedo [35] which includes 4 items. The service value scales were adopted from Wang et al. [55] and Sweeney \& Soutar [56] which have been tested in Vietnam by Hau \& Thuy [31] including process value (4 items) and outcome value (4 items). All the scales were adjusted to the health care service context.

\section{RESULTS}

The survey was conducted by directly interview patients who came to hospitals and clinics in HCMC for their health examination and treatment. Of the 300 approached patients, 289 responded the survey. However, 26 of 289 unqualified cases were eliminated. Table 1 shows key characteristics of the sample. In this sample, around $70 \%$ respondents are younger than 35 years old; and the frequency of using health care service more than one time is around $75 \%$ in total of sample. $90 \%$ of the sample includes people with income lower than 15 millions.

Table 1. Sample characteristics

\begin{tabular}{|l|c|c|l|l|c|}
\hline & Frequency & $\%$ & & Frequency & $\%$ \\
\hline Gender & 111 & 42.2 & Single & 112 & 42.6 \\
\hline Male & 152 & 57.8 & Married, no child & 25 & 9.5 \\
\hline Female & & Married with child & 126 & 47.9 \\
\hline & & & & \\
\hline Age & 32 & 12.2 & $35-44$ & 61 & 23.2 \\
\hline$<25$ & 118 & 44.9 & $\geq 55$ & 52 & 19.7 \\
\hline $25-34$ & & & Frequency of using service/year & \\
\hline Income & 97 & 36.9 & 1 time & 63 & 23.95 \\
\hline$<5$ millions & 88 & 33.5 & $2-3$ times & 134 & 50.95 \\
\hline $5-10$ millions & 51 & 19.4 & $4-6$ times & 48 & 18.25 \\
\hline $10-<15$ millions & 27 & 10.3 & $>6$ times & 18 & 6.85 \\
\hline$\geq 15$ millions & 27 & & \\
\hline
\end{tabular}

\section{Validity and reliability of measures}

Exploratory factor analysis was first employed to preliminary check construct validity and 14 variables were eliminated, then confirmatory factor analysis (CFA) was conducted in AMOS [2]. The distributions of variables showed kurtosis values within -0.473 to +0.882 and skewness values range from 0.790 to +0.175 which proved that it is appropriate for maximum likelihood (ML) estimation to be applied (Kline, 1998). The CFA of the full measurement model with the remaining 17 items yielded the following measures: $\chi^{2}=173.058 ; \mathrm{df}=91 ; \mathrm{p}=0.000 ; \chi^{2} / \mathrm{df}$ $=1.902 ; \mathrm{GFI}=0.925 ; \mathrm{TLI}=0.956 ; \mathrm{CFI}=$ 0.970 ; RMSEA $=0.059$. It is also noted there is no requirement being violated [28].

Besides, results showed that all item loadings on operant firm resources, perceive value and customer word-of-mouth constructs range from 0.668 to 0.928 indicating satisfactory convergent validity. Discriminant validity was also satisfactory as the correlations between 28 pairs of constructs resulted in the range from

\section{Trang 148}


0.304 to 0.834 which are well below 1 . The composite reliability of the constructs range from 0.75 and 0.89 and the extracted variances ranged from 0.53 to 0.90 , all exceed acceptable standards for exploratory research [37] (Refer Table 2).

Table 2. Results of correlations and squared root of AVE

\begin{tabular}{|l|r|r|r|r|r|r|c|c|c|}
\hline & AVE & WOM & OV & PV & SR & OP & E & SF & RR \\
\hline Word of Mouth (WOM) & 0.65 & $\mathbf{0 . 8 0 5 *}$ & & & & & & & \\
\hline Outcome value (OV) & 0.76 & 0.663 & $\mathbf{0 . 8 7 2 *}$ & & & & & & \\
\hline Process value (PV) & 0.80 & 0.631 & 0.828 & $\mathbf{0 . 8 9 4}$ & & & & & \\
\hline Social Relation (SR) & 0.74 & 0.322 & 0.519 & 0.505 & $\mathbf{0 . 8 6 0} *$ & & & & \\
\hline Operation Process (OP) & 0.72 & 0.433 & 0.646 & 0.547 & 0.304 & $\mathbf{0 . 8 4 2} *$ & & & \\
\hline Expertise (E) & 0.75 & 0.565 & 0.637 & 0.624 & 0.404 & 0.453 & $\mathbf{0 . 8 6 6 *}$ & & \\
\hline Staff Interaction (SI) & 0.53 & 0.584 & 0.814 & 0.834 & 0.408 & 0.666 & 0.679 & $\mathbf{0 . 7 2 6 *}$ & \\
\hline $\begin{array}{l}\text { Representational } \\
\text { Resources (RR) }\end{array}$ & 0.81 & 0.671 & 0.646 & 0.625 & 0.335 & 0.393 & 0.619 & 0.531 & $\mathbf{0 . 9 0 0 *}$ \\
\hline
\end{tabular}

Note: (*): Squared root of AVE

Structural model estimation and hypothesis testing

Next, the structural equation model was estimated using ML method. The result showed the research model fit the data satisfactorily: $\chi^{2}$ $=227.293 ; \mathrm{df}=107 ; \mathrm{p}=0.000 ; \chi^{2} / \mathrm{df}=2.124$; GFI $=0.899 ;$ TLI $=0.945 ;$ CFI $=0.957$; RMSEA $=0.06$. The results (Figure 1) indicated that Cultural Resource has a strongest significant standardized effect $(\beta=0.733 ; \mathrm{p}=$ 0.036), the next one is Representational Resources $(\beta=0.239 ; p=0.023)$ and the weakest significant standardized effect is Social Relation $(\beta=0.126 ; \mathrm{p}=0.039)$ on Service Value. Service Value in turn has a strongly significant standardized effect on word-ofmouth $(\beta=0.718 ; \mathrm{p}=0.025)$.

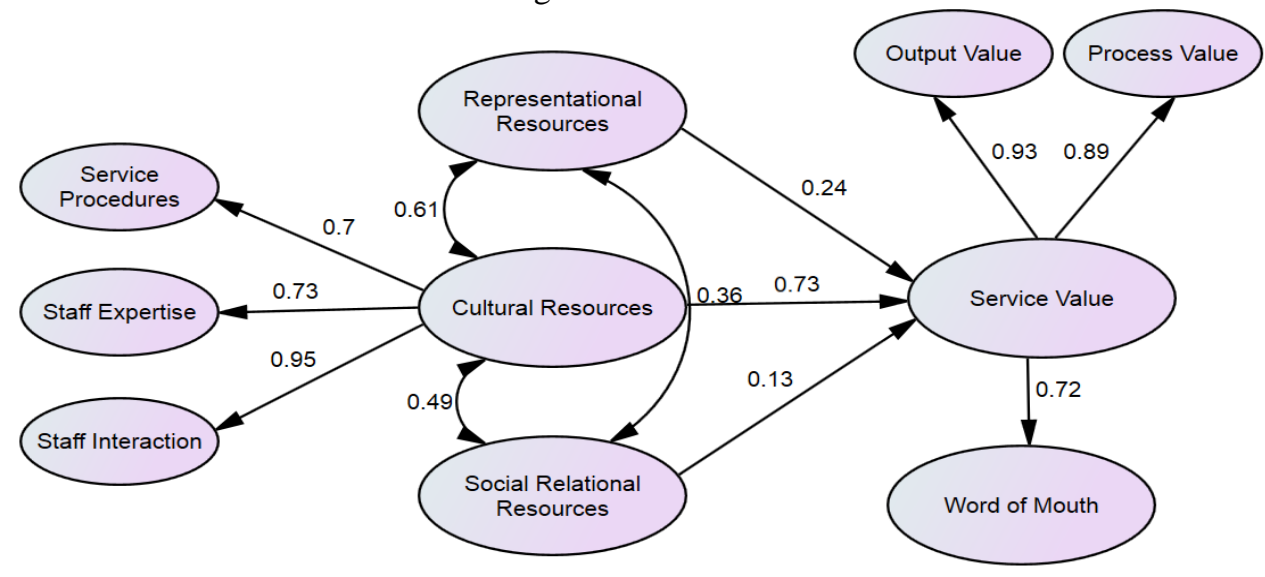

Figure 2. Result model of firm's operant resources and service value 
The results also show that three standardized coefficients representing the reflective paths from cultural resource (second-order construct) to its three dimensions (first-order construct) were Service process $(\beta=0.703$; Expertise $(\beta=$ 0.728; Staff Interaction $(\beta=0.948)$. Another second-order construct Service Value has been reflected by Outcome Value $(\beta=0.927)$ and then Process Value $(\beta=0.894)$. All of the hypotheses are supported in this study. The hypothesis testing result shows in Table 2.

Table 3. Standardized estimates

\begin{tabular}{|l|l|r|c|c|}
\hline & \multicolumn{1}{|c|}{ Hypothesis } & $\begin{array}{c}\text { Standardized } \\
\text { Coefficients }\end{array}$ & Sig. & Result \\
\hline H1 (+) & Representational Resource $\rightarrow$ Service Value & 0.24 & $* *$ & Supported \\
\hline H2 (+) & Cultural Resource $\rightarrow$ Service Value & 0.73 & $* *$ & Supported \\
\hline H3 (+) & Social Resource $\rightarrow$ Service Value & 0.13 & $* *$ & Supported \\
\hline H4 (+) & Service Value $\rightarrow$ Word-of-Mouth effect & 0.72 & $* *$ & Supported \\
\hline
\end{tabular}

Note: (*): sig. at $95 \%$

\section{DISCUSSIONS}

This research focuses on how customer's perception of a firm's operant resources affects his or her perceived value by conducting the empirical test in the health care service. The results show that all three components of firms' operant resources (i.e., representational resources, cultural resources and social resources) positively affect the perceived service value. In other words, a positive assessment of customers on firms' operant resources enhances their perception of service value, leading to customers' positive word-of- mouth.

Particularly, there reveal different impacts of three forms of operant resources. Culture resource has the strongest influence on customer perceived value of service ( $\beta=0.733$ ). In health care context, the physician's expertise, enthusiastic interaction and efficient service process (fast and accurate administrative procedures) are the required and requisite conditions. Moreover, patients come to see the physician with the primary need to diagnose, cure and receive advice related to their health problems. Therefore, they would care less about the trade-off between hospital reputation
(Representational Resource) and the relationship of this hospital and other health service centers/other hospitals as well as its relationship with community (Social Resources)

The interaction between suppliers and customers increases the chance they influence each other in a process (service process and the service used) [26]. In the health care industry, the interaction between physician and patient is the nature of service providing process. This dialogue would be information collection for further procure process and methods. Consultation requires time, patience, active thinking and behavior of the doctor which might affect to recognizing the health problem and solution making. A good interaction requires qualities, skills and the willingness from the doctor. The interaction between doctor and patient (communication through the information exchange) has impacted significantly on the results of examination and treatment. The results directly affected to the service value of the patients when they use medical services. This result is also in line with the research of McColl-Kennedy, Vargo, Dagger, Sweeney \& van Kasteren [41] which showed that the value 
evaluation of treatment process in health care service related to the interactions between individuals and their doctors [42; 41]. For physician expertise, following S-D logic mindset, expertise factor is considered as a nonphysical important resource [34; 5] including doctor's specialized skills, know-how and knowledge and experience. Patients could easily observe and assess those resources during their medical examinations [13; 6]. Moreover, health services have direct impacts on people health and lives. The accurate service is paramount requirement which need to be controlled via doctor's skills. Therefore, based on observations of skillfully performing professional tasks of doctors, patients can perceived the service value compared to their time and efforts spending for the service. Service procedure in health care service included the registration procedure, payment procedures, time on process. In the customer point of view, the simpler administration procedure the less time and effort customer need to spend. Besides, patients using health services often worried about their health situation; therefore, they do not want to psychologically wait during the medical examination.

The relationships of the two remain constructs of operant firm resources between representational resource and social relational resources and service value have weaker impacts than cultural resources, with $\beta=0.239$ and $\beta=0.126$ respectively. Since representational resources and social relational resources did not directly affect to patients' bodies and procure health care examination. They usually relate to hospital reputation and its relationship with other partners, so their roles in deriving value to customer is smaller than cultural resources, consequently. Service value has a significant impact on word of mouth with $\beta=0.73$ which is consistent with previous studies.

The significance of this paper is to explore whether customers' view on firms' operant resources affects their perception of value cocreated. The result proved that customers perceive not only how strong process and how good usage operant resources of a firm to be in creating/offering the service outcomes/profits, but how strong and how favorite customers' view on operant resources would make customers perceive more value.

\section{CONCLUSION}

In an attempt to examine how a customer's view on firm's operant resources affect his or her perception of value co-created by both parties, this research conducted an empirical test in health care service in Ho Chi Minh city. This research enriches our understanding of firm's operant resources being viewed from customer side, which has received relatively little attention from service marketing literature. As being commonly understood, firm operant resources create service value by better exploiting operand resource and other operant resources [48; 49]. This study shows that positive views of customers on firm operant resources also lead to their better value perception.

The results of this study provide a base for drawing managerial implications. Accordingly, service providers should invest in training professional skills for service encounters to enhance the quality of interaction, to encourage staff to show professional service procedure during service process. Besides, service providers could increase their service competitive advantages by reducing complicated administrative procedure in service process (e.g., well-setup system with clear and wellconducted service process) to create a fast and 
convenient service access for the customer with his/her minimal effort participation.

Although the study meets the research objectives, it still has some limitations needed to be considered for future research. First, the data were collected in HCMC only. Second, this study has relied on a limited set of sub- dimensions of the focal constructs. Further research may add other components to discover more antecedents of service value. Third, together with the customer view of a firm's operant resources, further research may want to explore the view of the other side. 


\section{Nguồn lực tương tác của doanh nghiệp và giá trị dịch vụ theo quan điểm của khách hàng sử dụng dịch vụ $\mathrm{y}$ tế}

- Phạm Ngọc Thúy

- Nguyễn Trần Cẩm Linh

- Nguyễn Tiến Dũng

- Phạm Tiến Minh

Trường Đại Học Bách Khoa, ĐHQG HCM - Email: pnthuy@hcmut.edu.vn

\section{TÓM TẮT}

Bài báo nhằm khảo sát nhận thức của khách hàng đối với tác động của nguồn lục tuoong tác của doanh nghiệp (bao gồm nguồn lục đại diện, nguồn lự văn hóa và nguồn lự xã họi) lên giá trị dịch vu trong một ngành dịch vu có mức độ tuoong tác cao với khách hàng. Nghiên cứu được thưc hiện trên 263 bệnh nhân

ở Việt Nam. Kết quả cho thấy, theo quan điểm của khách hàng, các thành phần của nguồn lực tuoong tác của doanh nghiệp đều có tác động tích cưc đến giá trị dịch vu. Trong đó, nguồn lực văn hóa có tác động lớn nhất. Phần thảo luận kết quả và hàm ý quản trị cũng được trình bày. tế.

Tù khóa: nguồn lực tuoong tác của doanh nghiệp, giá trị dịch vu, hiệu ứng truyền miệng, dịch vu y

\section{REFERENCES}

[1]. Abdolvand, M. A., \& Norouzi, A. The Effect of Customer Perceived Value on Word of Mouth and Loyalty in B-2-B Marketing. Research Journal of Applied Sciences, Engineering and Technology, 4(23), 4973-4978 (2012).

[2]. Arbuckle, J. L., \& Wothke, W. Amos 4.0. Chicago, IL: Smallwaters (1999).

[3]. Auh, S., Bell, S. J., McLeod, C. S., \& Shih, E. Co-production and customer loyalty in financial services. Journal of retailing, 83(3), 359-370 (2007).

[4]. Babin, B. J., \& James, K. W. A brief retrospective and introspective on value. European Business Review, 22(5), 471-478 (2010).

[5]. Baron, D. P. A positive theory of moral management, social pressure, and corporate social performance. Journal of Economics \& Management Strategy, 18(1), 7-43 (2009).

[6]. Baron, S., \& Warnaby, G. Value co-creation from the consumer perspective. In Service Systems Implementation (pp. 199-210). Springer US (2011).

[7]. Bolton, R. N., Smith, A. K., \& Wagner, J. Striking the right balance designing service to enhance business-to-business relationships. Journal of Service Research, 5(4), 271-291 (2003). 
[8]. Borch, O. J., Huse, M., \& Senneseth, K. Resource configuration, competitive strategies, and corporate entrepreneurship: An empirical examination of small firms. Entrepreneurship Theory and Practice, 24(1), 49-70 (1999).

[9]. Brady, M. K., \& Cronin Jr, J. J. Some new thoughts on conceptualizing perceived service quality: a hierarchical approach. Journal of marketing, 65(3), 34-49 (2001).

[10]. Chan, K. W., Yim, C. K., \& Lam, S. S. KIs customer participation in value creation a doubleedged sword? evidence from professional financial services across cultures. Journal of Marketing,74(3), pp. 48-64 . (2010)..

[11]. Chaudhuri, A. How brand reputation affects the advertising-brand equity link. Journal of Advertising Research, 42(3) (2002).

[12]. Chen, S. C., \& Quester, P. G. Modeling store loyalty: perceived value in market orientation practice. Journal of Services Marketing, 20(3), 188-198 (2006).

[13]. Clulow, V., Barry, C., \& Gerstman, J. The resource-based view and value: the customer-based view of the firm. Journal of European Industrial Training, 31(1), 19-35 (2007).

[14]. Constantin, J. A., \& Lusch, R. F. Understanding resource management. Oxford, OH: The Planning Forum (1994).

[15]. Dabholkar, P. A. How to improve perceived service quality by improving customer participation. In B. J. Dunlap (Ed.), Developments in Marketing Science (pp. 483-487). NC: Journal of the Academy of Marketing Science (1990).

[16]. Dagger, T. S., Sweeney, J. C., \& Johnson, L. W. A hierarchical model of health service quality scale development and investigation of an integrated model. Journal of Service Research, 10(2), 123-142 (2007).

[17]. Dees, J. G., \& Starr, J. A. Entrepreneurship through an ethical lens: Dilemmas and issues for research and practice. In D. L. Sexton, \& J. D. Kasarda (Eds.), The state of the art of entrepreneurship (pp. 89-116). Kent Publishing, Boston (1992).

[18]. Donabedian, A. The role of outcomes in quality assessment and assurance. Quality Review Bulletin, 18(11), 356-360 (1992).

[19]. Donckels, R., \& Lambrecht, J. Networks and small business growth: an explanatory model. Small Business Economics, 7(6), 273-289 (1994)..

[20]. Ferguson, R. J., Paulin, M., \& Leiriao, E. Loyalty and positive word-of-mouth: patients and hospital personnel as advocates of a customer-centric health care organization. Health marketing quarterly, 23(3), 59-77 (2007).

[21]. Foreyt, J. P., \& Poston, W. S. C. The role of the behavioral counselor in obesity treatment. Journal of the American Dietetic Association, 98(10), S27-S30 (1998).

[22]. Grönroos, C. A service quality model and its marketing implications. European Journal of marketing, 18(4), 36-44 (1984).

[23]. Grönroos, C. Service management and marketing: managing the moments of truth in service competition. Jossey-Bass (1990).

[24]. Grönroos, C. (2004). The relationship marketing process: communication, interaction, dialogue, value. Journal of Business \& Industrial Marketing, 19(2), 99-113.

[25]. Grönroos, C. Service logic revisited: who creates value? And who co-creates?. European Business Review, 20(4), 298-314 (2008).

[26]. Grönroos, C. Value co-creation in service logic: A critical analysis. Marketing Theory, 11(3), 279-301 (2011).

\section{Trang 154}


[27]. Gummesson, E., \& Mele, C. Marketing as value co-creation through network interaction and resource integration, Journal of Business Market Management, 4(4), 181-198 (2010).

[28]. Hair Jr, J. F., Black, W. C., Babin, B.J., Anderson, R. E., \& Tatham, R. L. Multivariate Data Analysis, 6 (2006).

[29]. Harrison-Walker, L. J. The measurement of word-of-mouth communication and an investigation of service quality and customer commitment as potential antecedents. Journal of Service Research, 4(1), 60-75 (2001).

[30]. Hartline, M. D., \& Jones, K. C. Employee performance cues in a hotel service environment: Influence on perceived service quality, value, and word-of-mouth intentions. Journal of Business Research, 35(3), 207-215 (1996).

[31]. Hau, L. N., \& Thuy, P. N. Impact of service personal values on service value and customer loyalty: a cross-service industry study. Service Business-An International Journal, 6(2), 137-155 (2012).

[32]. Heinonen, K. Reconceptualizing customer perceived value: the value of time and place. Managing Service Quality: An International Journal, 14(2/3), 205-215 (2004).

[33]. Heinonen, K., Strandvik, T., \& Voima, P. Customer dominant value formation in service. European Business Review, 25(2), 104-123 (2013).

[34]. Hunt, S. D. A responsibilities framework for marketing as a professional discipline. Journal of Public Policy \& Marketing, 26(2), 277-283 (2007).

[35]. Jurisic, B., \& Azevedo, A. Building customer-brand relationships in the mobile communications market: The role of brand tribalism and brand reputation. Journal of Brand Management, 18(4), 349-366 (2011).

[36]. Khalifa, A. S. Customer value: a review of recent literature and an integrative configuration. Management Decision, 42(5), 645-666 (2004).

[37]. Kline RB Principles and Practice of Structural Equation Modeling. Guilford Press, New York (1998) (1998).

[38]. Lovelock, C., Patterson, P. G., \& Walker, R. HServices Marketing, London, Prentice Hall (2001)

[39]. Madhavaram, S., Granot, E., \& Badrinarayanan, V. Relationship marketing strategy: an operant resource perspective. Journal of Business \& Industrial Marketing, 29(4), 275-283 (2014).

[40]. Madhavaram, S., \& Hunt, S. D, The service-dominant logic and a hierarchy of operant resources: developing masterful operant resources and implications for marketing strategy. Journal of the Academy of Marketing Science, 36(1), 67-82 (2008).

[41]. McColl-Kennedy, J. R., Vargo, S. L., Dagger, T. S., Sweeney, J. C., \& van Kasteren, Y. Health care customer value cocreation practice styles. Journal of Service Research, 1094670512442806 (2012).

[42]. Michie, S., Miles, J., \& Weinman, J. Patient-centredness in chronic illness: what is it and does it matter? Patient Education and Counseling, 51(3), 197-206 (2003).

[43]. Musa, R., Pallister, J., \& Robson, M. The roles of perceived value, perceived equity and relational commitment in a disconfirmation paradigm framework: An initial assessment in a relationship-rich' consumption environment. Advances in Consumer Research, 32, 349 (2005).

[44]. Rust, R. T., \& Oliver, R. W. The death of advertising. Journal of Advertising, 23(4), 71-77 (1994).

[45]. Schneider, B., \& Bowen, D. E. Winning the service game (pp. 31-59). Springer US (2010). 
[46]. Spence, M. Competitive and optimal responses to signals: An analysis of efficiency and distribution. Journal of Economic Theory, 7(3), 296-332 (1974).

[47]. Sweeney, J. C., Soutar, G. N., \& Mazzarol, T. Factors influencing word of mouth effectiveness: receiver perspectives. European Journal of Marketing,42(3/4), 344-364 (2008).

[48]. Vargo, S. L., \& Lusch, R. F. Evolving to a new dominant logic for marketing. Journal of Marketing, 68(1), 1-17 (2004).

[49]. Vargo, S. L., \& Lusch, R. F. Service-dominant logic: continuing the evolution. Journal of the Academy of Marketing Science, 36(1), 1-10 (2008).

[50]. Wang, Y., Lo, H-P., \& Hui,Y-V. The antecedents of service quality and product quality and their influences on bank reputation: evidence from the banking industry in China. Managing Service Quality: An International Journal, 13(1), $72-83$ (2003).

[51]. Wensing, M., Grol, R., \& Smits, A. Quality judgements by patients on general practice care: a literature analysis. Social Science \& Medicine, 38(1), 45-53 (1994).

[52]. Woodruff, R. B. Customer value: the next source for competitive advantage. Journal of the Academy of Marketing Science, 25(2), 139-153 (1997).

[53]. Zeithaml, V. A. Consumer perceptions of price, quality, and value: a means-end model and synthesis of evidence. The Journal of Marketing, 2-22 (1988).

[54]. Zifko-Baliga, G. M., \& Krampf, R. F. Managing perceptions of hospital quality. Negative emotional evaluations can undermine even the best clinical quality. Marketing health services, 17(1), 28-35 (1996).

[55]. Wang, Y., Po Lo, H., Chi, R., \& Yang, Y. An integrated framework for customer value and customer-relationship-management performance: a customer-based perspective from China. Managing Service Quality: An International Journal, 14(2/3), 169-182 (2004).

[56]. Sweeney, J. C., \& Soutar, G. N. Consumer perceived value: The development of a multiple item scale. Journal of retailing, 77(2), 203-220 (2001).

Appendix 1: Measurement scale and results.

\begin{tabular}{cc}
\hline Item wording & $\begin{array}{c}\text { Std } \\
\text { loading }\end{array}$ \\
\hline
\end{tabular}

Outcome value (composite reliability $=0.86$, average variance extracted $=0.76$ )

The benefits I receive from $\mathrm{X}$ are high values

The service at $\mathrm{X}$ provides me with the benefits I want

The value I received from $X$ is as good as expected

Deleted

$X$ provides me service at high standard

Deleted

Process value (composite reliability $=0.89$, average variance extracted $=0.80$ )

The doctor at $\mathrm{X}$ makes me feel good during the time I used the service

The doctor at $\mathrm{X}$ give me a positive experience during the time I use the service

I have an assurance time during the time I use the service at $\mathrm{X}$

Deleted

I have happy time during the service at $\mathrm{X}$

Deleted

\section{Trang 156}


Representational resources $($ composite reliability $=0.89$, average variance extracted $=0.81$ )

$\mathrm{X}$ is an reliable health care center 0.88

$\mathrm{X}$ is an reputable health care center

$X$ is a prestigious health care center

Deleted

Social Relation (composite reliability $=0.85$, average variance extracted $=0.74$ )

$\mathrm{X}$ has good relationships with partners

$\mathrm{X}$ has good relationships to the community

$X$ has good relationship with patients

Deleted

Service Procedure (composite reliability $=0.83$, variance extracted $=0.72$ )

$\mathrm{X}$ has easy and convenient administrative procedures

$\mathrm{X}$ create fast administrative procedures

0.86

$X$ is well managed

Deleted

$X$ 's working hours fit my personal circumstances

Deleted

Staff Expertise (composite reliability $=\mathbf{0 . 8 5}$, variance extracted $=\mathbf{0 . 7 5}$ )

I believe the staff at the clinic are highly skilled at their jobs.

Doctors have good experiences

The staff at the clinic carry out their tasks competently.

Deleted

You can rely on the staff at the clinic to be well trained and qualified

Deleted

Staff Interaction (composite reliability $=0.75$, variance extracted $=0.53$ )

The staff at X explain things in a way that I can understand.

The staff at $\mathrm{X}$ are concerned about my well-being.

The staff at $\mathrm{X}$ always listen to what I have to say

I feel the staff at $X$ understand my needs

Deleted

The clinic's staff treat me as an individual and not just a number.

Deleted

I find it easy to discuss things with the staff at the clinic.

Deleted

The staff and I sometimes kid around, laugh, or joke with each other like close friends

Deleted

The staff at the clinic are willing to answer my questions.

Deleted

WOM (composite reliability $=0.78$, variance extracted $=0.65)$

I will share experiences about the health care center for the others

I would highly recommend the clinic to other patients

I have said positive things about the clinic to my family and friends

Deleted

I will feedback for health care center to improve service quality

Deleted 